\title{
Novel mutation in the myelin protein zero gene in a family with intermediate hereditary motor and sensory neuropathy
} F L Mastaglia, K J Nowak, R Stell, B A Phillips, J E Edmondston, S M Dorosz,
S D Wilton, J Hallmayer, B A Kakulas, N G Laing

Objectives-To determine the molecular
basis for autosomal dominant intermedibasis for autosomal dominant intermediate hereditary motor and sensory neuropathy (HMSN) in a four generation family. The gene defects in families with intermediate HMSN are not known, but it has been suggested that most have $\mathrm{X}$ linked HMSN. Methods-All participating family members were examined clinically. Genomic DNA was obtained from 10 affected and seven unaffected members. Linkage analysis for the known HMSN loci was first performed. Mutations in the periph-
eral myelin protein zero gene (PMP0) were sought in two affected members, using one unaffected member for comparison, by amplification of the six exons of the gene followed by single strand conformation polymorphism (SSCP) analysis, dideoxy fingerprinting (ddF), tion was screened for in all affected and Alu I digestion and in 100 unrelated control subjects using "snap back" SSCP analysis. Sequencing of cDNA from a sural nerve biopsy from an affected member was also performed.

Results-The clinical phenotype was of variable severity, with motor nerve conduction velocities in the intermediate range. Linkage to PMP0 was demonstrated. Analysis of genomic DNA and cDNA for PMP0 identified a novel codon 35 GAC to TAC mutation. The mutation produces an inferred amino acid change of aspartate to tyrosine at codon six of the processed protein (Asp6Tyr) in the extracellular domain and was present in all affected family members but not in 100 unrelated controls.

Conclusions-The present findings further extend the range of phenotypes associated with PMP0 mutations and indicate that families with "intermediate" HMSN need not necessarily be $\mathrm{X}$-linked as previously suggested.

(F Neurol Neurosurg Psychiatry 1999;67:174-179)

Keywords: intermediate Charcot-Marie-Tooth disease; myelin protein zero gene; missense mutation

Cases of autosomal demyelinating hereditary motor and sensory neuropathy (HMSNI or
CMT1) have been associated with duplications of, or point mutations in, the PMP-22 gene on chromosome $17 \mathrm{p} 11.2$ (CMT1A), ${ }^{12}$ or, less often, with mutations in the peripheral myelin protein zero gene (PMP0) on chromosome 1q22-23 (CMT1B). ${ }^{3-5}$ The neuronal form (HMSNII, CMT2) has been linked to loci at 1p35-p36, ${ }^{6}$ 3q13-q22, ${ }^{7}$ and 7 p14, ${ }^{8}$ but no mutated gene has been identified. Linkage to and mutation of PMPO have also been reported in families with HMSNII. ${ }^{9-12}$ Finally, mutations in PMP0 have been described in isolated cases of Dejerine-Sottas disease (HMSNIII) ${ }^{13}{ }^{14}$ and congenital hypomyelination. ${ }^{15}$

The gene defects in families with a clinical phenotype and nerve conduction velocities intermediate between those of HMSNI and II ("intermediate" HMSN) are not known, but it has been suggested that most, if not all, such families have the X-linked form of HMSN $(\mathrm{HMSN}-\mathrm{X})^{16}{ }^{17}$ which has been associated with mutations in the connexin 32 gene $(\mathrm{Cx} 32)$ on Xq13. ${ }^{18}{ }^{19}$ Linkage to the known HMSNI and II loci was not found in a previously reported Italian family with autosomal dominant intermediate HMSN and it was concluded that the intermediate form of HMSN is a separate entity. ${ }^{20}$

We report here the finding of a novel mutation in the PMP0 gene in a four generation family of Macedonian origin with autosomal dominant HMSN characterised by a clinical phenotype of variable severity and motor nerve conduction velocities in the intermediate range. Linkage of the disease in this family to the PMP0 region was previously reported in abstract form. ${ }^{21}$

\section{Methods}

CLINICAL STUDIES

The family tree is shown in figure 1. Of ten known affected members, two were deceased. Six of the eight living affected family members were available for clinical examination and nerve conduction studies. In the two who were not available for examination, the diagnosis had been made previously by one of us (BAK). Fourteen asymptomatic family members were also examined. Motor and sensory nerve conduction were measured in the median and ulnar nerves using standard techniques in use in this department. ${ }^{22} \mathrm{~A}$ sural nerve biopsy was performed in two affected members (II.6, III.8). 
Table 1 Primers used to amplify $P$ zero genomic DNA and cDNA

\begin{tabular}{|c|c|c|}
\hline & Forward primer 5' to $3^{\prime}$ & Reverse primer 5' to 3' \\
\hline \multicolumn{3}{|c|}{ Genomic DNA } \\
\hline Exon 1 & GACACAAAGCCCTCTGTGTA & CTCCCAAGACTCCCAGAGTA $†$ \\
\hline Exon 2 & CCATAGGTGCATCTGATTC & TTCTGTTATCCAACCCCAG \\
\hline Exon 3 & ATGCTTCCССТCATTCСTC & GCCTGAATAAAGGTCCTTAGGC* \\
\hline Exon 4 & TAGGAACCACAGATACAGG & ACCCACTGGAGTAGTCTC \\
\hline Exon 5 & GAAGAGGAAGCTGTGTCCGC* & CACATCAGTCACCGAGCGACT* ${ }^{\star}$ \\
\hline Exon 6 & AGTCGCTCGGTGACTGATGTG & CСACСССТАACСССCGATC \\
\hline \multicolumn{3}{|l|}{ cDNA } \\
\hline & TCAACCCCACAGATGCTCCGG & \multirow{4}{*}{ TCACAAGTGAACGTGCC } \\
\hline (B) & GTCTTTGAAAAAGTGCCAAC & \\
\hline (C) & & \\
\hline (D) & CGCATCCAGTGGGTAGGGGAC & \\
\hline
\end{tabular}

*Taken from Nelis et $a l^{4}$

+GDB primer M49 - http://gdbwww.gdb.org

The others were picked from the sequence in Pham-Dinh et $a l^{5}$

MOLECULAR STUDIES

Genomic DNA

Genomic DNA was extracted from peripheral blood from 10 affected and seven unaffected family members.

Linkage analysis

Microsatellite markers were analysed according to standard procedures in this laboratory. ${ }^{23}$

\section{Exonic amplification}

The six exons of PMP0 were amplified individually using the primer pairs listed in table 1. Each $25 \mu 1$ polymerase chain reaction (PCR) volume consisted of $100 \mathrm{ng}$ of each primer pair, $50 \mathrm{ng}$ genomic DNA, $2 \mathrm{mM}$ $\mathrm{MgCl}_{2}, 200 \mu \mathrm{M}$ of each deoxynucleotide triphosphate, $0.55 \mathrm{U}$ Tth Plus DNA polymerase (Biotech International Ltd), and $2.5 \mu 110 \mathrm{X}$ reaction buffer (Biotech International Ltd). Amplification conditions for all exons were an initial $94^{\circ} \mathrm{C}$ for 4.5 minutes followed by 35 cycles of $94^{\circ} \mathrm{C}$ for 30 seconds, 1 minute at $58^{\circ} \mathrm{C}$, and 45 seconds at $72^{\circ} \mathrm{C}$. Gel purified products of each of the exons were analysed for single stranded conformation polymorphisms (SSCPs). ${ }^{26}{ }^{27}$ To increase the likelihood of mutation detection, various gel fractionation conditions were used. These included 19:1, $29: 1,37.5: 1$, and 99:1 polyacrylamide gel ratios, $1: 3$ and 1:7 DNA to formamide loading buffer (FLB) (deionised formamide, $10 \mathrm{mM}$ $\mathrm{NaOH}, 0.05 \%$ bromophenol blue, $0.05 \%$ xylene cyanol) ratios for samples, and electrophoresis at room temperature and $4^{\circ} \mathrm{C}$, and at $200 \mathrm{~V}$ or $400 \mathrm{~V}$.

\section{Dideoxy fingerprinting}

Dideoxy fingerprinting (ddF), ${ }^{28}$ was performed using radiolabelled dideoxy terminators and thermostable sequenase (Amersham Life Sciences). Approximately 100 ng purified PCR product from each exon was reamplified for 55 cycles using the same parameters as above. After mixing the samples with the manufacturer's stop solution, a $4 \mu \mathrm{l}$ aliquot was denatured for 3 minutes at $94^{\circ} \mathrm{C}$ before electrophoresis through a $6 \%, 29: 1$ non-denaturing polyacrylamide gel for 2 hours 10 minutes at $35 \mathrm{~W}$. A 1.2 $\mathrm{X}$ and $0.8 \mathrm{X}$ TBE buffer concentration was used in the gel and the running buffer respectively. Biomax MR film (Kodak) was exposed overnight with the radioactive gel.

\section{Sequencing}

Polymerase chain reaction products for sequencing were purified from unreacted primers and nucleotides using QIAquick PCR spin columns (QIAgen) as described by the manufacturer. The purified products were sequenced using the $\mathrm{ABI}$ BigDye ${ }^{\mathrm{TM}}$ terminator kit and the same primers as used for the initial exonic amplifications and analysed on an ABI 373A automated sequencer.

\section{Alu I digestion}

A forward mismatch primer was designed, 5'-CCCAGGCCATCGTGGTTTACAGC-3', which would introduce an Alu I enzyme site only if the putative mutation was present. This primer was used with the original exon 2 reverse primer to amplify exon 2 of the genomic DNA using the same PCR conditions as for all the exonic amplifications. The PCR products were ethanol precipitated and then digested with Alu I (Promega) according to the manufacturer's directions. Digestion products were electrophoresed through a 12\%, 29:1

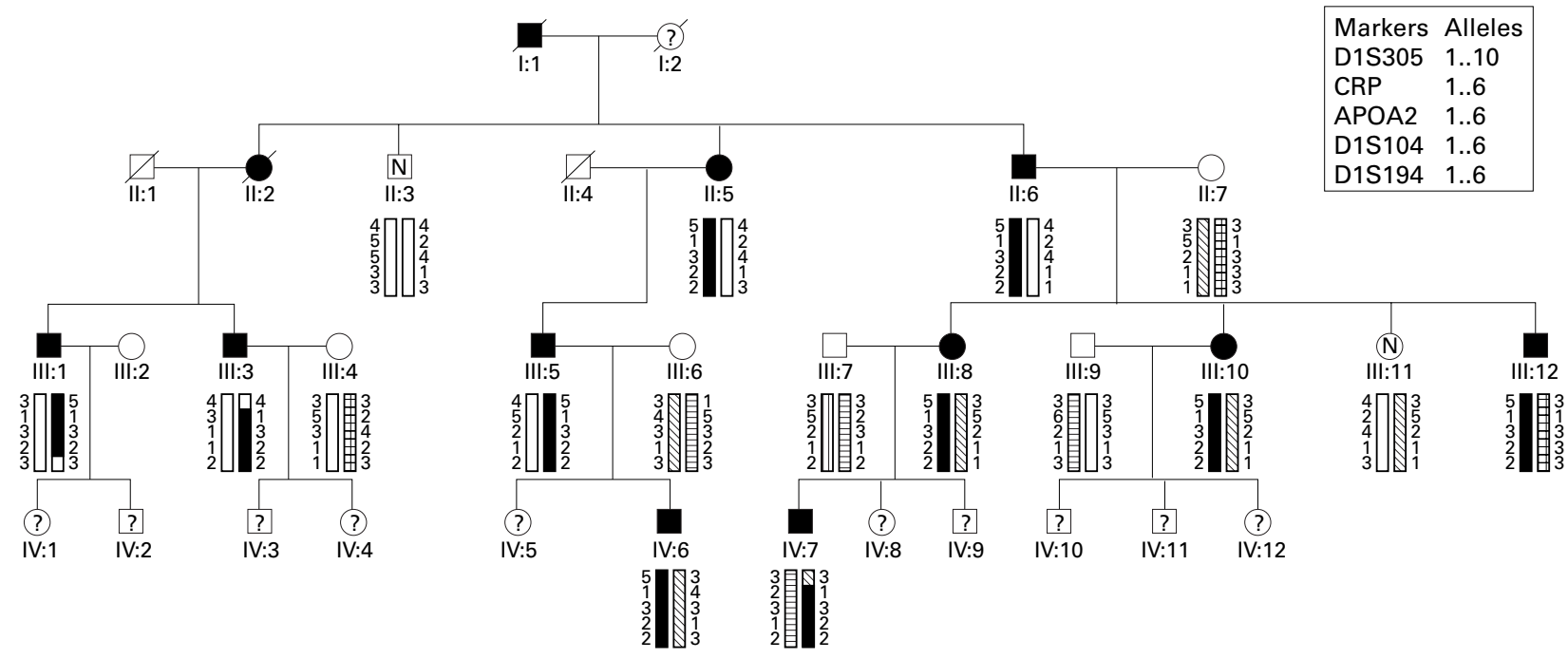

Figure 1 Pedigree of the family, showing the conserved haplotype for loci CRP, APOA2, and D1S104 and the recombinations with D1S305 and D1S194. 


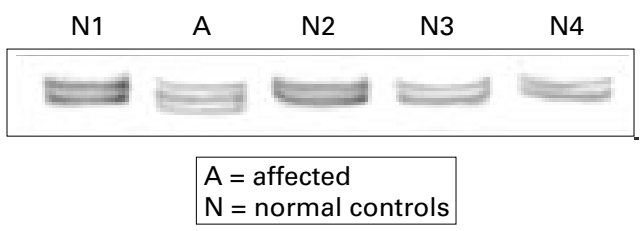

Figure 2 SSCP analysis of $P$ zero gene exon 2 in one affected member and four controls.

non-denaturing polyacrylamide gel at $250 \mathrm{~V}$, for 1.5 hours at room temperature. Bands were visualised by silver staining. ${ }^{29}$

Snap back SSCP analysis

A snap back primer ${ }^{30}$ for exon 2, 5'- ACAC CGACAGTTCTGTTATCCAACCCCAG-3', was designed to screen 100 unrelated, normal controls. This reverse primer was used with the original exon 2 forward primer to amplify genomic DNA. Apart from the new primer, the previous PCR mixture was used, with amplification conditions at $94^{\circ} \mathrm{C}$ for 4.5 minutes followed by 38 cycles of $94^{\circ} \mathrm{C}$ for 30 seconds, $60^{\circ} \mathrm{C}$ for 45 seconds, and $72^{\circ} \mathrm{C}$ for 45 seconds. A $3 \mu$ aliquot from each amplification solution was mixed with $9 \mu \mathrm{l}$ of $\mathrm{FLB}$ and denatured at $96^{\circ} \mathrm{C}$ for 3 minutes before being cooled on ice. Chilled samples were electrophoresed through a 12\%, 29:1 nondenaturing polyacrylamide gel at $400 \mathrm{~V}$ for 1 hour 45 minutes. The gel system was packed in ice to maintain a temperature of less than $18^{\circ} \mathrm{C}$. Bands were visualised by silver staining (fig 2). ${ }^{29}$

\section{cDNA analysis}

RNA was extracted from the nerve biopsy from patient II.6 using TRI REAGENT ${ }^{\mathrm{R}}$ (MRC Inc). Total RNA ( $2 \mu \mathrm{g})$ was used to synthesise first strand cDNA with $\mathrm{M}-\mathrm{MLV}$ reverse transcriptase (Perkin-Elmer). The P0 coding region was amplified with the cDNA A primer in the 5' UTR (table 1), and the exon 6 reverse primer in the 3'UTR (table 1). The $25 \mu \mathrm{l} \mathrm{PCR}$ mixture was as for the genomic amplifications above, with about $10 \%$ of the total cDNA sample being amplified by a denaturation step at $94^{\circ} \mathrm{C}$ for 4.5 minutes, followed by 40 cycles of $94^{\circ} \mathrm{C}$ for 30 seconds, $55^{\circ} \mathrm{C}$ for 1 minute, and $72^{\circ} \mathrm{C}$ for 1 minute. The product was sequenced using $\mathrm{ABI}$ BigDye ${ }^{\mathrm{TM}}$ terminator kits as for the genomic DNA sequencing, with three internal cDNA primers $\mathrm{B}, \mathrm{C}$, and $\mathrm{D}$ (table 1) as well as those used for the original cDNA amplification.

\section{Results}

CLINICAL STUDIES

In addition to the eight known affected members, two of the asymptomatic members (fig 1: IV.6, IV.7) were also found to be affected clinically and had abnormal nerve conduction studies (table 2).

Affected members displayed a symmetric pattern of distal muscle atrophy, weakness, and sensory impairment in the lower limbs and to a lesser extent in the upper limbs, with depression of deep tendon reflexes. Weakness of knee and hip flexors was present in some of the more severely affected members. Sensory involvement was present in five of the eight cases. As shown in table 2, there was considerable variability in the severity of motor and sensory involvement which was most severe in two affected women in their $50 \mathrm{~s}$. A mild postural and kinetic upper limb tremor was present in three cases. There was no palpable thickening of peripheral nerve trunks in any of the affected members. As shown in table 2, the motor nerve conduction velocities varied from $24-41 \mathrm{~m} / \mathrm{s}$ for the median nerve and from 33-48 m/s for the ulnar nerve. Sensory nerve action potentials at the wrist were markedly delayed and attenuated in all affected members.

\section{NERVE BIOPSY}

In II: 6 there was advanced fibre loss with few residual myelinated fibres. In III:8 there was non-selective drop out of myelinated fibres. Light and electron microscopy and teased fibre preparations showed evidence of axonal degeneration. There was no onion bulb formation. Teased fibre preparations also showed some thinly myelinated internodes suggesting segmental demyelination and remyelination. Neither tomacula nor fibres with uncompacted myelin sheaths were found.

\section{MOLECULAR STUDIES}

Linkage studies

The pedigree, with DNA available from 10 affected members (fig 1), was large enough to obtain significant evidence of linkage to candidate loci in the human genome. Linkage analysis was begun with the known loci for CMT1A, the peripheral myelin protein gene (PMP22) on chromosome $17,{ }^{131} \mathrm{CMT} 1 \mathrm{~B}$, the peripheral myelin PMP0, ${ }^{35}$ and $\mathrm{CMT}_{2} \mathrm{~A}^{6}$ on chromosome 1. Recombinations with markers D17S839, D17S921, and D17S922 within and flanking the CMT1A duplication region on

Table 2 Summary of clinical details and motor nerve conduction velocities in eight affected patients

\begin{tabular}{|c|c|c|c|c|c|c|c|c|c|}
\hline \multirow[b]{2}{*}{ Patient } & \multirow[b]{2}{*}{ Sex } & \multirow[b]{2}{*}{ Age } & \multirow{2}{*}{$\begin{array}{l}\text { Duration of } \\
\text { symptoms }(y)\end{array}$} & \multicolumn{2}{|c|}{ Weakness * } & \multirow[b]{2}{*}{ Sensory loss } & \multirow{2}{*}{$\begin{array}{l}\text { Upper limb } \\
\text { tremor }\end{array}$} & \multicolumn{2}{|c|}{$M C V(\mathrm{~m} / \mathrm{s}) \dagger$} \\
\hline & & & & $U L$ & $L L$ & & & Median & Ulnar \\
\hline II:6 & $M$ & 77 & 20 & $4-$ & $4-$ & Severe & Yes & 35 & 43 \\
\hline III:3 & $\mathrm{M}$ & 59 & 1 & $4+$ & 3 to $4-$ & Nil & No & 40 & 48 \\
\hline III:5 & $M$ & 56 & $>20$ & $4+$ & 2 to $3-$ & Mild & No & 37 & 42 \\
\hline III:8 & $\mathrm{F}$ & 53 & 12 & 3 to $4-$ & 0 & Severe & No & 24 & 37 \\
\hline III: 10 & $\mathrm{~F}$ & 50 & 10 & 3 to $4-$ & 0 & Severe & Yes & 41 & 44 \\
\hline III:12 & M & 38 & 1 & $4-$ & $4-$ & Nil & No & 30 & 33 \\
\hline IV:6 & $\mathrm{M}$ & 31 & $\mathrm{~A} / \mathrm{s}$ & 5 & 4 to $4+$ & Nil & Yes & 38 & 47 \\
\hline IV:7 & $\mathrm{M}$ & 34 & $\mathrm{~A} / \mathrm{s}$ & 5 & $5-$ & Mild & No & 35 & 45 \\
\hline
\end{tabular}

${ }^{\star} \mathrm{MRC}$ grades for distal muscle groups in upper (UL) and lower (LL) limbs. $\mathrm{A} / \mathrm{S}=$ asymptomatic; $\mathrm{MCV}=$ motor conduction velocity in elbow to wrist segment.

†Normal ranges for this laboratory: median 58 (SD 3.8) m/s, ulnar 58 (SD 3.4) m/s. 


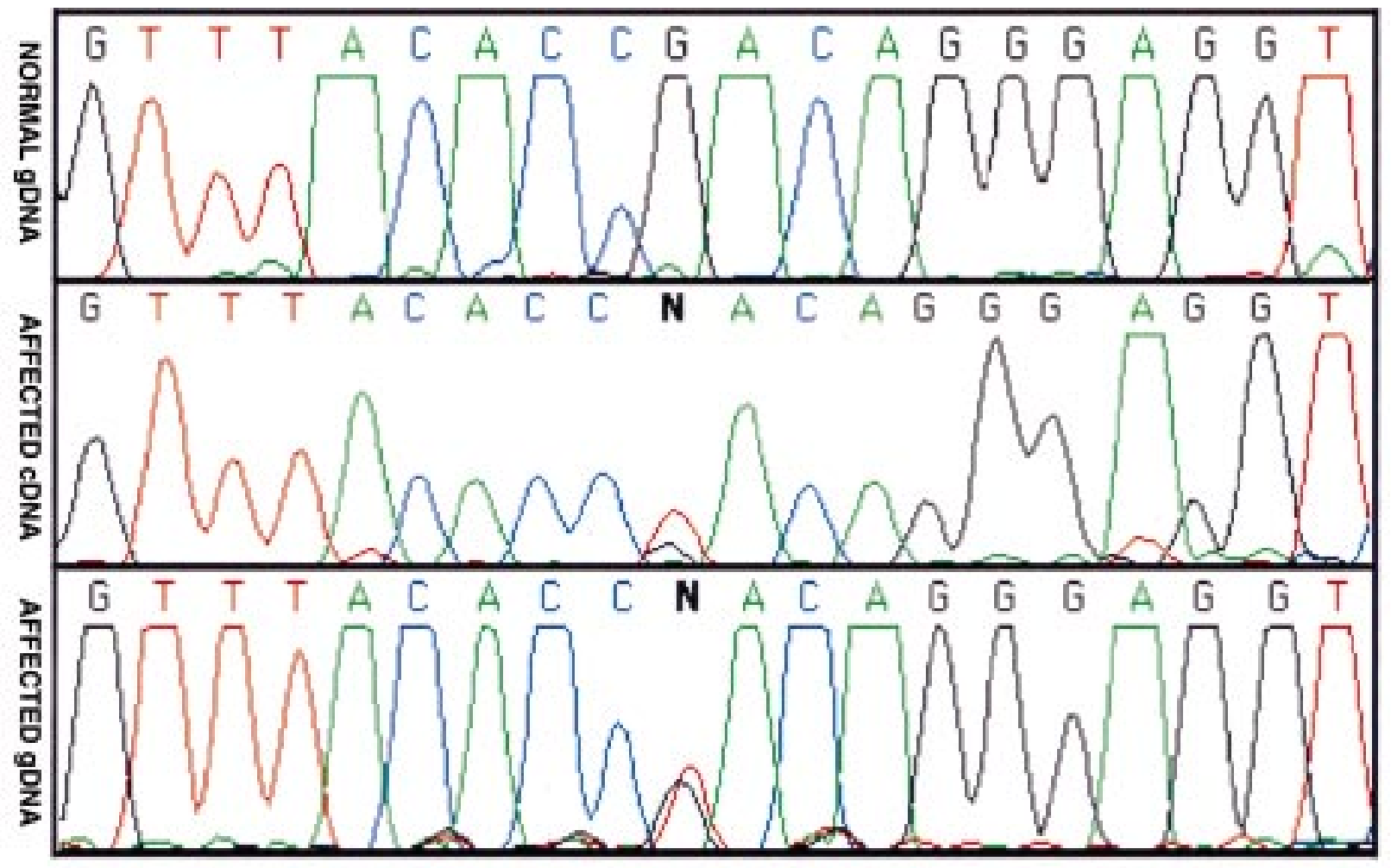

Figure 3 Heterozygote sequencing of exon 2 using automated sequencing. The mutation is seen as a double $T$ and $G$ peak in both cDNA and genomic $D N A$.

chromosome 17 and two point LOD scores, calculated with the FASTLINK version of MLINK, ${ }^{32-34}$ of less than -2.00 allowed exclusion of the CMT1A region. The CMT2A locus was similarly excluded. For the CMT1B region on chromosome 1 however, no recombinations were seen with the markers CRP, APOA2, and D1S104 (fig 1). The multipoint LOD score calculated with the FASTLINK version of LINKMAP, using a dominant fully penetrant model, ignoring the unaffected members in generation IV and using a disease gene frequency of 0.0001 , was 3.12 at both CRP and APOA2.

Genomic DNA analysis

The six exons of PMP0 were amplified from two affected family members and one normal member. The amplicons from affected mem- bers were compared with normal controls by SSCP analysis ${ }^{26}{ }^{27}$ under a range of conditions, but no polymorphisms were detected. The amplified products from each exon were then analysed by dideoxy fingerprinting $(\mathrm{ddF})^{28}$ which indicated differently migrating species in exon 2 for the affected samples compared with the normal. Sequencing of the PCR products from exon two of two affected members and one control indicated a heterozygous change from GAC to TAC (aspartate to tyrosine) at codon 35 of the cDNA (numbered according to the Human Gene Mutation Database ${ }^{35}$ ) (fig 3). Codon 35 is the equivalent of amino acid 6 of the processed protein ${ }^{15}{ }^{36}$ and the inferred amino acid change may therefore be designated Asp6Tyr. Polymerase chain reaction products of exon 2 from all 10 affected members amplified using the mismatch primer which intro-

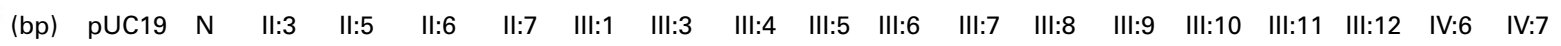

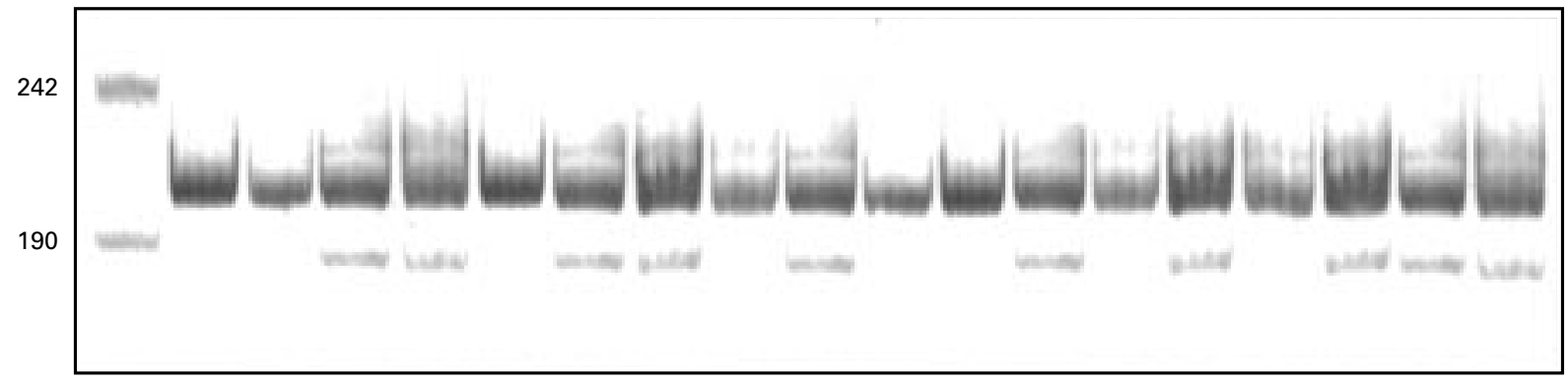

Figure 4 Alu I digest of the myelin protein zero gene exon 2 amplicons using the mismatch primer. $N=$ normal control, other lane numbers correspond to the members in the pedigree in fig 1. All affected members show the smaller Alu I digestion product expected from the mutation. 
duces an Alu I site when the mutation is present, showed a smaller, $171 \mathrm{bp}$ product, after Alu I digestion. Polymerase chain reaction products from the unaffected members did not (fig 4). An SSCP was obtained using the snap back primer amplicons in samples from all affected family members, but from none of 100 unrelated, normal controls. Sequencing the PCR products for all other exons from two affected members and one control gave no evidence of any other mutation.

cDNA analysis

Sequencing of the entire coding region of the PMP0 cDNA from one affected member and one control confirmed the presence of the codon 35 mutation at the cDNA level and gave no evidence of any other mutation.

\section{Discussion}

The two main types of HMSN (types I and II) have traditionally been differentiated on the basis of reduced motor nerve conduction velocities and pathological evidence of a hypertrophic demyelinating peripheral neuropathy in type I and relative preservation of conduction velocities and axonal degeneration in type II. ${ }^{37-39}$ A motor conduction velocity in the median nerve of $30 \mathrm{~m} / \mathrm{s}^{40}$ or $38 \mathrm{~m} / \mathrm{s}^{41}$ has variably been suggested as an arbitrary cut off level for separating HMSN types I and II, although it has been recognised that there is a certain amount of overlap between the two types. The nosological status of patients and families with borderline motor nerve conduction velocities in the $30-40 \mathrm{~m} / \mathrm{s}$ range has been unclear and such families have been referred to as having intermediate HMSN in the literature. ${ }^{42}{ }^{43}$ Harding $^{17}$ suggested that most, if not all, such families have the X-linked form of HMSN. In X-linked HMSN, there is considerable variability in clinical and neurophysiological features with, in general, males being more severely affected than females, who may be mildly affected or asymptomatic. ${ }^{45}$ The family reported here was considered to have intermediate HMSN on the basis of borderline motor nerve conduction velocities similar to those in X-linked families. The nerve biopsy results were more consistent with HMSN II. The pattern of inheritance was clearly autosomal dominant and, by contrast with HMSN-X families, two females were more severely affected than the males.

Point mutations in PMP0 were first described in CMT1B by three groups in $1993^{3-5}$ and subsequently confirmed by other groups. ${ }^{46}$ Mutations in PMP0 have since been reported in association with a wide range of phenotypes. These have included severe early onset disease conforming to the Dejerine-Sottas syndrome $^{13} 1447$ and families classified as HMSN type II with Ser15Phe ${ }^{10}$ or Thr124Met mutations. ${ }^{112}$ The Asp6Tyr missense mutation found in the present family has not previously been reported but is consistent with previously published PMP0 mutations, most of which have been missense or nonsense substitutions in exons 2 or 3 , the portion of the gene coding for the extracellular and transmembrane do- mains of the protein. ${ }^{17}$ It is of interest that the mutation Thr5Ile, at a neighbouring amino acid to that mutated in the present study, results in classic HMSN type I, with conduction velocities $<10 \mathrm{~m} / \mathrm{s}$ in the median nerve. ${ }^{48}$

The finding of a mutation in PMP0 in the present family with intermediate HMSN adds to the range of phenotypes associated with PMP0 mutations. The failure to find a mutation in PMP0 in the intermediate HMSN family reported by Villanova et $a l^{20}$ indicates that there is genetic heterogeneity in the intermediate form of HMSN as in HMSNI and HMSNII.

Peripheral myelin protein zero is the major structural component of peripheral nervous system myelin, and is an integral membrane glycoprotein belonging to the immunoglobulin superfamily which is encoded by six exons. ${ }^{49}$ The protein has a homophilic extracellular domain which is thought to act as an adhesion molecule and to play an important role in the compaction of the myelin sheath. ${ }^{49}{ }^{50} \mathrm{~A}$ mutation in the extracellular domain of the protein could therefore interfere with the normal formation and maintenance of the myelin sheath. Meijerink et $a l^{47}$ found increased numbers of fibres with uncompacted myelin sheaths and evidence of myelin breakdown on electron microscopy in two patients with heterozygous Arg69His and Arg69Cys mutations, whereas Thomas $e t a \bar{l}^{11}$ found a tomaculous neuropathy in those with identified PMP0 mutations. In the present study, a sural nerve biopsy in two affected persons showed evidence of both axonal degeneration and segmental demyelination with loss of myelinated nerve fibres, but did not show these other changes. There is thus also a considerable variation in the pathological phenotype in those with confirmed PMP0 mutations.

Recent studies employing transfected insect cell lines have indicated a possible correlation between cellular adhesion capability and the severity of the clinical phenotype with different PMP0 point mutations. ${ }^{52}$ More detailed genotype-phenotype correlation may come from the study of transgenic mice expressing dominant PMP0 mutations.

This work was funded by the National Health and Medical Research Council of Australia Project Grant 960592 and the Research Council of Australia Project Grant 960592 and the
Neuromuscular Foundation of Western Australia. We are grateful to Dr G Danta and Dr A Kermode who performed nerve ful to Dr G Danta and Dr A Kermode who performed nerve
conduction studies in two of the subjects, and to Dr L Middleconduction studies in two of the subjects, and to Dr L Middle-
ton and Professor A D Roses for helpful discussions in the early stages of the study. Mrs S Moncrieff provided secretarial assistance.

1 Lupski JR, de Oca-Luna RM, Slaugenhaupt S, et al. DNA duplication associated with Charcot-Marie-Tooth disease type 1A. Cell 1991;66:219-32.

2 Valentijn LJ, Baas F, Wolterman RA, et al. Identical point mutations of PMP-22 in Trembler-J mouse and CharcotMarie-Tooth disease type 1A. Nat Genet 1992;2:288-91.

3 Hayasaka K, Himoro M, Sato W, et al. Charcot-MarieTooth neuropathy type $1 \mathrm{~B}$ is associated with mutations of the myelin Po gene. Nat Genet 1993;5:31-4.

4 Kulkens T, Bolhuis PA, Wolterman RA, et al. Deletion of the serine 34 codon from the major peripheral myelin protein Po gene in Charcot-Marie-Tooth disease type 1B. Nat Genet 1993;5:35-9.

$5 \mathrm{Su}$ Y, Brooks DG, Li L, et al. Myelin protein zero gene mutated in Charcot-Marie-Tooth disease type $1 \mathrm{~b}$ patients. Proc Natl Acad Sci USA 1993;90:10856-60.

6 Othmane KB, Middleton LT, Loprest LJ, et al. Localization of a gene (CMT2A) for autosomal dominant Charcot- 
Marie-Tooth disease type 2 to chromosome $1 \mathrm{p}$ and evidence of genetic heterogeneity. Genomics 1993;17:3705 .

7 Kwon JM, Elliot JL, Yee W-C, et al. Assignment of a second Charcot-Marie-Tooth type II locus to chromosome 3q. Am f Hum Genet 1995;57:853-8.

8 Ionasescu V, Searby C, Sheffield VC, et al. Autosomal dominant Charcot-Marie-Tooth axonal neuropathy mapped on chromosome 7p (CMT2D). Hum Molec Genet 1996;5: 1373-5.

9 Chapon F, Lechevalier B, Schaeffer S, et al. A family presenting with electrophysiological "CMT type II" and
linked to the Po gene. Neuromusc Disord 1997;7:472.

10 Marrosu MG, Vaccargiu S, Marrosu G, et al. CharcotMarie-Tooth disease type 2 associated with mutation of the myelin protein zero gene. Neurology 1998;50:1397-401.

11 De Jonghe P, Timmerman V, Van Broeckhoven C. 2nd Workshop of the European CMT Consortium: 53rd ENMC International Workshop on Classification and Diagnostic Guidelines for Charcot-Marie-Tooth type 2 (CMT2-HMSNII) and distal hereditary motor neuropathy (CMT2-HMSNII) and distal hereditary motor neuropathy (Distal HMN-spinal CMT) 26-28 September 1997, Naar

12 Haites NE, Nelis E, Van Broeckhoven C. 3rd workshop of the European CMT consortium: 54th ENMC international workshop on genotype/phenotype correlations in Charcot-Marie-Tooth type 1 and hereditary neuropathy with liability to pressure palsies. 28-30 November 1997 Naarden, The Netherlands. Neuromusc Disord 1998;8:591603.

13 Hayasaka K, Himoro M, Sawaishi Y, et al. De novo mutation of the myelin Po gene in Dejerine-Sottas disease (hereditary motor and sensory neuropathy type III). Nat Genet 1993;5:266-8.

14 Rautenstrauss B, Nelis E, Grehl H, et al. Identification of a de novo insertional mutation in Po in a patient with a Déjérine-Sottas syndrome (DSS) phenotype. Hum Molec Dejerine-Sottas syndrom $1994 ; 3: 1701-2$.

15 Warner LE, Hilz MJ, Appel SH, et al. Clinical phenotypes of different MPZ (P0) mutations may include Charcot-
Marie-Tooth type 1B, Dejerine-Sottas, and congenital Marie-Tooth type 1B, Dejerine-Sottas,
hypomyelination. Neuron 1996;17:451-60.

16 Nicholson G, Nash J. Intermediate nerve conduction velocities define X-linked Charcot-Marie-Tooth neuropathy families. Neurology 1993;43:2558-64.

17 Harding AE. From the syndrome of Charcot, Marie and Tooth to disorders of peripheral myelin proteins. Brain 1995;118:809-18.

18 Bergoffen J, Scherer SS, Wang S, et al. Connexin mutations in X linked Charcot-Marie-Tooth disease. Science 1993; 262:2039-42.

19 Fairweather N, Bell C, Cochrane S, et al. Mutations in the connexin 32 gene in X linked dominant Charcot-Marie-

Tooth disease (CMTX1). Hum Molec Genet 1994;3:29-34. Marie-Tooth-disease: an intermediate form. Neuromusc Marie-Tooth-disease:

21 Stell R, Mastaglia FL, Phillips B, et al. Linkage to the myelin protein zero locus in a family with intermediate HMSN. 1997;7:470.

22 Knezevic W, Mastaglia FL. Neuropathy associated with Brescia-Cimino arteriovenous fistulas. Arch Neurol 1984; 41:1184-6.

23 Beggs AH, Phillips HA, Kozman H, et al. A (CA)n repeat polymorphism for the skeletal muscle $\alpha$-actinin gene ACTN2 and its localisation on the CEPH consortium linkage map of chromosome 1. Genomics 1992;13:1314-15.

24 Nelis E, Timmermann V, De Jonghe P, et al. Rapid screening of myelin genes in CMT1 patients by SSCP analysis: identification of new mutations and polymorphisms in the Po gene. Hum Genet 1994;94:653-7.

25 Pham-Dinh D, Fourbil Y, Blanquet F, et al. The major peripheral myelin protein zero gene: structure and localization in the cluster of $\mathrm{Fc} \gamma$ receptor genes on human chromosome 1q21.3-q23. Hum Mol Genet 1993;2:2051-4.

26 Orita $M$, Iwahana $\mathrm{H}$, Kanazawa $\mathrm{H}$, et al. Detection of polymorphisms of human DNA by gel electrophoresis as single strand conformation polymorphisms. Proc Natl Acad Sci USA 1989;86:2766-70.

27 Orita M, Suzuki Y, Sekiya T, et al. Rapid and sensitive detection of point mutations and DNA polymorphisms using the polymerase chain reaction. Genomics 1989;5:8749.
28 Sarkar G, Yoon H-S, Sommer SS. Dideoxy fingerprinting (ddf): a rapid and efficient screen for the presence of mutations. Genomics 1992;13:441-3.

29 Bassam BJ, Caetano-Anolles G, Gresshoff PM. Fast and sensitive silver staining of DNA in polyacrylamide gels. Anal Biochem 1991;196:80-3.

30 Wilton SD, Honeyman K, Fletcher S, et al. Snapback SSCP analysis: engineered conformation changes for the rapid typing of known mutations. Hum Mutat 1998;11:252-8.

31 Patel PI, Roa BB, Welcher AA, et al. The gene for the peripheral myelin protein PMP-22 is a candidate for peripheral myelin protein PMP-22 is a candidate for 159-65.

32 Cottingham Jr RW, Idury RM, Schaffer AA. Faster sequential genetic linkage computations. Am f Hum Genet 1993;53:252-63.

33 Schaffer AA, Gupta SK, Shriram K, et al. Avoiding recombination in linkage analysis. Hum Hered 1994;44:225-37.

34 Lathrop GM, Lalouel JM. Easy calculations of lod scores and genetic risks on small computers. Am f Hum Genet 1984;36:460-5.

35 Krawczak M, Cooper DN. The human gene mutation database. Trends Genet 1997;13:121-2

36 Kirschner DA, Szumowski K, Gabreels-Festen AAWM, et al. Inherited demyelinating peripheral neuropathies: relating myelin packing abnormalities to P0 molecular defects. $\mathcal{F}$ Neurosci Res 1996;46:502-8.

37 Dyck PJ, Lambert EH. Lower motor and primary sensory neuron diseases with peroneal muscular atrophy. I. Neurologic, genetic, and electrophysiologic findings in hereditary polyneuropathies. Arch Neurol 1968;18:603-18.

38 Thomas PK, Calne DB. Motor nerve conduction velocity in peroneal muscular atrophy: evidence for genetic heterogeneity. $\mathcal{F}$ Neurol Neurosurg Psychiatry 1974;37:68-75.

39 Buchthal F, Behse F. Peroneal muscular atrophy (PMA) and related disorders. I. Clinical manifestations as related to biopsy findings, nerve conduction and electromyography. Brain 1977;100:41-66.

40 Harding AE, Thomas PK. The clinical features of hereditary motor and sensory neuropathy types I and II. Brain 1980:103:259-80.

41 de Visser M. Diagnostic criteria for autosomal dominant hereditary motor and sensory neuropathy type Ia. Neuromusc Disord 1993;3: 77-9.

42 Brust JCM, Lovelace RE, Devi S. Clinical and electrodiagnostic features of Charcot-Marie-Tooth syndrome. Acta Neurol Scand 1978; (suppl 68):1-142.

43 Davis CJ, Bradley WG, Madrid R. The peroneal muscular atrophy syndrome: clinical, genetic, electrophysiological and nerve biopsy studies. I. Clinical, genetic and electro-

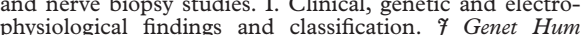
1978;26:311-49.

44 Rozear MP, Pericak-Vance MA, Fischbeck K, et al. Hereditary motor and sensory neuropathy, $\mathrm{X}$ linked: a half century follow up. Neurology 1987;37:1460-5.

45 Hahn AF, Brown WF, Kiiopman WJ, et al. X linked dominant hereditary motor and sensory neuropathy. Brain 1990;113:1511-25.

46 Patel PI, Lupski JR. Charcot-Marie-Tooth disease: a new paradigm for the mechanism of inherited disease. Trends Genet 1994;10:128-33.

47 Meijerink PHS, Hoogendijk JE, Gabreëls-Festen AAWM, et al. Clinically distinct codon 69 mutations in major myelin protein zero in demyelinating neuropathies. Ann Neurol protein zero in

48 Gabreels-Festen AAWM, Hoogendijk JE, Meijerink PHS, et al. Two divergent types of nerve pathology in patients with different Po mutations in Charcot-Marie-Tooth disease. Neurology 1996;47:761-5.

49 Uyemura K, Kitamura K, Miura M. Structure and molecular biology of Po protein. In: R. Martenson, ed. Myelin: biology and chemistry. Florida: CRC Press, 1992:481-507.

50 Giese KP, Martini R, Lemke G, et al. Mouse Po gene disruption leads to hypomyelination, abnormal expression of recognition molecules, and degeneration of myelin and axons. Cell 1992;71:565-76.

51 Thomas FP, Lebo RV, Rosoklija G, et al. Tomaculous neuropathy in chromosome 1 Charcot-Marie-Tooth syndrome. Acta Neuropathol 1994;87:91-7.

52 Rautenstrauss B. Genetic and biological aspects of Charcot Marie Tooth disease and related peripheral neuropathies. Acta Cardiomiologica 1996;8:53-7. 